\title{
気液平衡関係についで
}

一一第 4 報： 相関関係叔よび圧の影響—

平田光 穗**

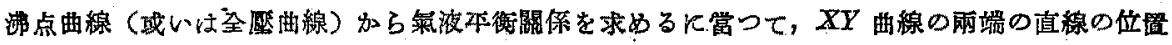

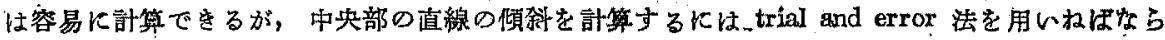

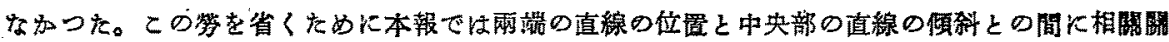

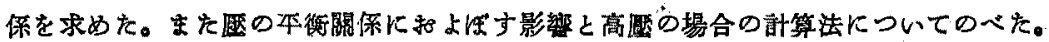

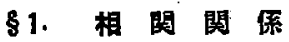

漂点対夜組成関係（或いは全圧対液組成関你）より氣 液平衡関係を求める計算法は前報怙よび前々報48) にの べた通りであるが， $X Y$ 曲線の中央部の直線の傾拣を計 算する火は，中央部位置する二点に対する溜点データ 多ら trial and error 法定用いていた。そ䚺算は簡單 なるのではすつても，実測值の誤差の影響等を考劣れば 触点たるをま妨れない。この缺点を除くためにる，ま

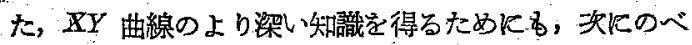
る相関閶係は有効なものであると信ずる。

$X Y$ 曲線家観察すれば答易にわかるように，上端の直 線 $Y=\alpha_{1}$ Xの座標 $\alpha_{1}$ が大になると，即ち直線の位置が 高をると（下端の直線の位置が同じならば）中央部の 直線の傾刹 $n$ る大となる。即ち傾斜が急になる。 はた下 端の直線 $Y=\alpha_{0} X 0.935$ の座標 $\alpha_{0}$ 少大になると，(上端 の直線の愔置が同じならば）中央部の直線の傾斜nは小 々なる。從つて，大さ゚つ゚にい党ば $n$ は $\alpha_{1}$ に正比例し

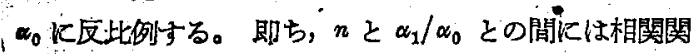
保方成立二管で每る。筆者は Table 1 にみられる如く， 両端の直線の位置がはつきりしている二成分系を得られ、 る限り集めて $\alpha_{1} / \alpha_{0}$ と $n$ 巨求めた。，它の結果を対数 方眼紙にブロットしたるのが Fig.1であり，その中特

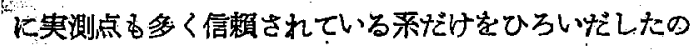
が Fig. 2 である。 $n=1$ の点は Raoult の法則に從5

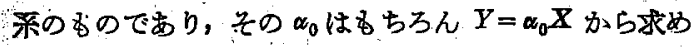

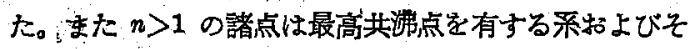
れに準ずる采に対するすのであつて，これらに対してる $\boldsymbol{\Delta}_{0}$ 结 $Y=\omega_{0} X$ 出ら計算した。即ち年れらの系の下端の

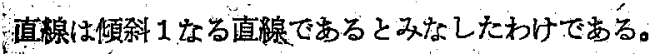

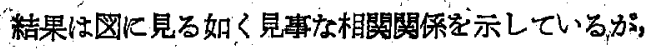

十昭和 25 月. 18 日好理

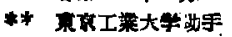

nが小さい部分では两端の直線の開きが大きくなつてく

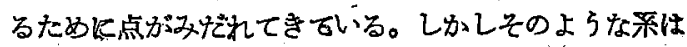
部分的にとけあう溶液の場合に近いのであつて，晋通の 系に対してはnは0.1よりる大となる。

な括，定圧に括ける本衡閣係る，定溫に怙けるるのる
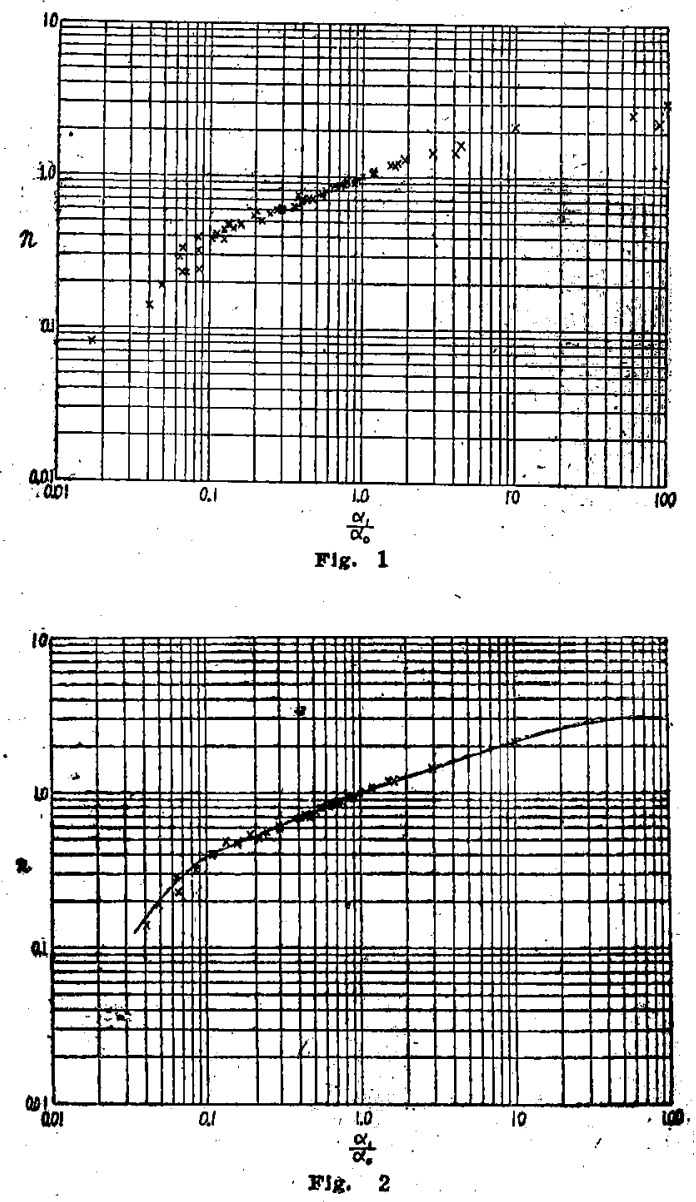

(Correlation Curve between al/ao and $n_{\text {.) }}$ 


\begin{tabular}{|c|c|c|c|c|c|}
\hline \multicolumn{6}{|c|}{ Table 1} \\
\hline System & Est. & $a_{0}$ & $a_{1}$ & $a_{1} / a_{0}$ & $n$ \\
\hline Acetone-Watex & 27 & 28.0 & 1.35 & 0.048 & 0.19 \\
\hline Acetone-Methanol & 42 & 1.9 & 0.85 & 0.447 & 0.72 \\
\hline Acetone-Fthanel & 12 & 2.8 & 1.45 & 0.518 & $0.75^{\circ}$ \\
\hline Acetone-n Bulanol & 4 & 10.0 & 17.0 & 1.70: & 1.21 \\
\hline Aceton $\_-B e n z e n e$ & 25 . & 2.6 & 1.4 & 0.539 & 0.77 \\
\hline Acetone:Cu larobenzene & 25 & 10.0 & 242 & $0.220^{\prime}$ & 0.50 \\
\hline Acetone-Acetic Acid & 25 & 3.6 & 16.0 & 4.45 & 1.63 \\
\hline $\mathrm{CS}_{2}-$-Acetone & 32 & 3.8 & 0.25 & 0.066 & 0.33 \\
\hline Benzene-- Ethylendichloride & 37 & 1.1 & 1.1 & 1.0 & 1.0 \\
\hline Bęnzene-Toluene & 45 & 2.5 & 2.5 & 1.0 & 1.0. \\
\hline Benzene-Ch lorobenzeno & 29 & 4.15 & 4.15 & 1.0 & 1.0 \\
\hline Etbano1-Benzene & 40. & 3.1 & 0.26 & 0.084 & 0.24 \\
\hline Ethanol-Berizene & 43 & 4.5 & 0.29 & Q.065 & 0.23 \\
\hline n Rexane-Benzen & 39 & 1.8 & 1.02 & 0.567 & 0.78 \\
\hline Acetaldeh yde-Benzene & 25 & 8.1 & 3.3 & 0.408 & 0.69 \\
\hline Meth yleth ylketone- & 38 & 1.02 & 0.91 & 0.892 & 0.91 \\
\hline Toluene-n Octane & 3 & 1.6 & 1.2 & $0.750^{\circ}$ & 0.88 \\
\hline Toluene-Acellic $\triangle$ cid & 25 & 2.8 & 0.4 & 0.143 & 0.45 \\
\hline $\mathrm{COI}_{4}$-Toluene & 32 & 2.3 & 2.3 & 1.0 & 1.0 \\
\hline $\begin{array}{c}\text { Eth glendichloride- } \\
\text { Toluene }\end{array}$ & 20 & 2.25 & 2.25 & 1.0 & 1.0 \\
\hline $\begin{array}{r}2,2,4 \text { Trineth ylpentane } \\
\text {-Toluene }\end{array}$ & 16 & 1.50 & 1.07 & 0.713 & 0.84 \\
\hline $\begin{array}{c}\text { Methyletbylketone- } \\
\text { Toluene }\end{array}$ & 38 & 2.75 & 1.83 & 0.665 & 0.85 \\
\hline n Heptane-Toluene & 38 & 1.55 & 1.10 & 0.710 & 0.87 \\
\hline Acetic Aeid- & 25 & 4.0 & 6.6 & 1.65 & 1.20 \\
\hline Acelio Acid-Xyleno & 25 & 6.8 & 0.56 & 0.083 & 0.39 \\
\hline Acelic Acid-Acetamide & 25 & 12.0 & 23.0 & 1.9 & 1.3 \\
\hline $\begin{array}{l}\text { Acetlo Acíd- } \\
\text { iso Amylacetate }\end{array}$ & 25 & 1.6 & 1.9 & 1.19 & 1.05 \\
\hline Acetic Acid- Butylacetate & 25 & 1.35 & 1.35 & 1.0 & 1.0 \\
\hline Äcetic Acide-Furfural & 25 & 3.0 & 3.6 & 1.20 & 1.08 \\
\hline $\begin{array}{l}\text { Acetic Acid-Melhyl } \\
\text { iso Anyllretone }\end{array}$ & $2 \dot{5}$ & 2.6 & 2.25 & 0.865 & 0.93 \\
\hline Walex-Acetic Acid & 9 & 1.65 & 1.35 & 0.820 & 0.935 \\
\hline Water-Acetic Aciád & 7 & 1.8 & 1.4 & 0.782 & 0.935 \\
\hline $\begin{array}{l}\text { Eth ylendichloride- } \\
\text { Acetic Aold }\end{array}$ & 25 & $3: 0$ & 4.6 & 1.53 & 1.2 \\
\hline $\begin{array}{r}\text { Propylacelale- } \\
\text { Acetic Acld }\end{array}$ & 25 & 1.6 & 1.2 & 0.75 & 0.88 \\
\hline Fornic Acid-Acetic Acld & 1 & 1.4 & 1.25 & 0.892 & 0.935 \\
\hline $\begin{array}{r}\text { Methyl zso butylketone } \\
\text { - Acetic Acid }\end{array}$ & 25 & 1.0 & 1.2 & $1: 2$ & 1.07 \\
\hline Water-Proplonfe Acid & 25 & 4.4 & 0.7 & 0.159 & 0.47 \\
\hline $\begin{array}{l}\text { Walex-2 Melhyl } \\
3 \text { Buly1 } 2 \text { ol }\end{array}$ & 7 & 3.0 & 0.05 & 0.017 & 0.08 \\
\hline MelhanoI-Water & 41 & 6.0 & 2,4 & 0.40 & 0.68 , \\
\hline
\end{tabular}

一情に同じ相関曲線上にのることは，與味深いことであ 万。

\section{2 中央直線の位置の決定}

前簷で得た相関関俰荣利用すれば，両端の直線の座標

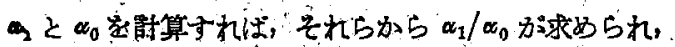

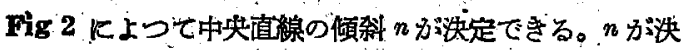
定されれば，第 2 報の (6) 式即ち

\begin{tabular}{|c|c|c|c|c|c|}
\hline System & Iult. & $\Delta 0$ & $a_{1}$ & $a_{1} / a_{0}$ & $n$ \\
\hline Methanoi-Water & 9 & 5.8 & 2.5 & $0: 43$ & 0.68 \\
\hline Ethanol-Water & 5 & 8.1 & 0.9 & 0.111 & 0.41 \\
\hline Ftbanol-Water & 30 & 7.9 & 0.86 & 0.109 & 0.40 \\
\hline Ethanol-Water & 9 & 8.5 & 0.87 & 0.102 & 0.38 \\
\hline n Propanol-Water & 15 & 9.4 & $0: 38$ & 0.040 & 0.14 \\
\hline Etrylacetate-Ethanol & 14 & 1.8 & 0.54 & 0.30 & 0.59 \\
\hline Ethylacetate-Ethanol & 18 & 1.8 & 0.53 & 0.295 & 0.61 \\
\hline $\mathrm{CCl}_{4}-n$ Propanól & 6 & 4.6 & 0.38 & 0.083 & 0.32 \\
\hline $\begin{array}{l}\text { iso Propylether- } \\
\text { iso Propasol }\end{array}$ & 22 & 3.6 & 0.48 & 0.133 & 0.47 \\
\hline n Butanol-Acetaldeh yde & 8 & 25.0 & 7.0 & 0.28 & 0.60 \\
\hline Acetaldeh yde-Firfural & 25 & 1.9 & 19.0 & 10.0 & 2.14 \\
\hline $\mathrm{CO}_{4}-$ Eth ylacetate & 36 & 1.2 & 0.77 & 0.642 & 0.83 \\
\hline $\mathrm{OS}_{2}-\mathrm{COl}_{4}$ & 32 & 2.5 & 2.1 & 0.84 & 0.935 \\
\hline $\begin{array}{l}\text { Methylethylketon- } \\
\text { Propionic Acid }\end{array}$ & 25 & 3.4 & 9.9 & 2.91 & 1.45 \\
\hline $\begin{array}{l}\text { Methylethylketone- } \\
\text { n Heptane }\end{array}$ & 38 & 4.2 & 0.56 & 0.133 & 0.48 \\
\hline$\beta$ Picoline-Phenol & 28 & 0.47 & 28.0 & 59.5 & 2.6 \\
\hline$\gamma$ Pigollne-Phenol & 28 & 0.19 & 20.0 & 105.0 & 3.1 \\
\hline 2,6 Futidine-Phenol & 28 & 0.33 & 29.0 & 88.0 & 2.3 \\
\hline$n$ Pentane-iso Pentane & 45 & 1.3 & 1.3 & 1.0 & 1.0 \\
\hline$n$ Heptane-n Octane & 3 & 1.5 & 1.1 & 0.733 & 0.88 \\
\hline $\begin{array}{l}n \text { Heptane- } \\
\text { Methylcyclohexane }\end{array}$ & 3 & 1.09 & 1.09 & 1.0 & 1.0 \\
\hline $2,2,4$ Trimeth ylpentane & 3 & 2.1 & 2.1 & 1.0 & 1.0 \\
\hline $\begin{array}{l}\text { 2,2,4 Trimethylpentane } \\
\text { - Methy lcyclohexane }\end{array}$ & 16 & 1.04 & 1.04 & 1.0 & 1.0 \\
\hline Njtrogen-Oxygen & 11 & $4.0^{\circ}$ & 4.0 & 1.0 & 1.0 \\
\hline Acetone-Methanol * & 23 & 2.8 & 1.0 & 0.357 & 0.63 \\
\hline Acetone-Ch loroform & 46 & 0.56 & 2.3 & 4.10 & 1.45 \\
\hline $\cos q-$ Acetone & 46 & 4.3 & 0.27 & 0.063 & 0.29 \\
\hline Fthylether-Acetone & 33 & 3.2 & 1.2 & 0.376 & 0.75 \\
\hline $\begin{array}{l}\text { Benzene- } \\
\text { Ethylendich Joride: }\end{array}$ & 46 & 1.15 & 1.15 . & 1.0 & 1.0 \\
\hline Benzene-iso Propanol & 24 & 6.0 & 0.42 & 0.07 & 0.23 \\
\hline Benzene-Cyclohexane & 35 & 1.1 & 0.7 & 0.636 & 0.85 \\
\hline Benzene-Toluene & 31 & 2.6 & 2.6 & 1.0 & $1.0^{\circ}$ \\
\hline $\mathrm{CCl}_{4}-$ Benzene & 46 & 1.1 & 1.0 & 0.91 & 0.935 \\
\hline $\mathrm{OS}_{2}$-Benzene & 33 & 4.2 & 2.4 & 0.57 & 0.80 \\
\hline MethanoI-Water & 13 & 6.2 & 3.4 & 0.55 & 0.72 \\
\hline Methazo1-Water & 44 & 10.0 & 3.6 & 0.36 & 0.62 \\
\hline Ethanol-Water & 10 & 3.6 & 0.45 & 0.125 & 0.37 \\
\hline Ohloroform-Ethanol & 34 & 4.2 & 0.52 & 0.124 & 0.44 \\
\hline Methylal $\sim \mathbf{C S}_{\mathbf{2}}$ & 46 & 2.2 & 0.55 & 0.25 & 0.56 \\
\hline $\mathrm{CCl}_{4}$-Eth ylacetate & 46 & 1.2 & 0.87 & 0.72 & 0.86 \\
\hline $\begin{array}{l}\text { Ethyleniodide- } \\
\text { Fthylacetate }\end{array}$ & 46 & 1.5 & 0.84 & 0.565 & $0.80^{3}$ \\
\hline
\end{tabular}

* Equilibria of the following systens were mensuxed hat constant temperature.

$$
\alpha=X^{1-n} \frac{n+k(1-x)}{n-k x}
$$

から，一点の沸点データによつて中央直線の座標 $\propto$ が 求められる。特に共沸点のある系では，云の組成に対底 する $\boldsymbol{X} \dot{X}_{m}$ であらわせば，その点は $k=0$ となるか ら上式は簡單に次式のよらになる。即ち

$$
\alpha=X_{m}^{1-n}
$$

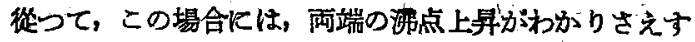




\begin{tabular}{|c|c|c|c|c|c|}
\hline \multirow[b]{2}{*}{$x$} & \multirow[b]{2}{*}{$\pi$} & \multicolumn{2}{|c|}{ Table 2} & \\
\hline & & $k$ & $k(1-x)$ & $n$ & $\alpha$ \\
\hline 0.9766 & 356.2 & 0.591 & $\begin{array}{l}0.014 \\
0.577\end{array}$ & 1 & 2.4 \\
\hline 0.0291 & 106.2 & 3.65 & $\begin{array}{l}3.544 \\
0.106\end{array}$ & 0.935 & 4.3 \\
\hline 0.4638 & 242.3 & 0.960 & $\begin{array}{l:}0.515 \\
0.445\end{array}$ & $\frac{a_{1}}{a_{0}}=0$. & $0.79 \rightarrow 3.67$ \\
\hline & & $\mathbf{T}$ & ble 3 & & \\
\hline$x$ & $T$ & $k$ & $\begin{array}{c}x(1-x) \\
k x\end{array}$ & $n$ & $\omega$ \\
\hline 0.975 & 340.8 & -1.23 & $\begin{array}{l}-0.03 \\
-1.20\end{array}$ & 1 & 0.441 \\
\hline 0.025 & 353.1 & 3.19 & $\begin{array}{l}3.11 \\
0.08\end{array}$ & 0.935 & 3.65 \\
\hline$x_{m}=3.6$ & + & 0 & $*$ & $\frac{a_{1}}{\dot{a}_{0}}=0.12$ & $125 \rightarrow 2.08$ \\
\hline
\end{tabular}

れば，中央の沸点データはなくとも（共饰点の組成は， Horkley の表 (Analytical Chem., 19, 508 (1947)), など からわかるので） $\alpha_{1}, \alpha_{0}, n$ 怙よび๙か浗められて $X Y$ 曲線は決定され得るのである。

\section{3. 実例}

a）三硫化炭素ーベンゾール 实測值は魰島 33)の $25^{\circ}$ ○に括けるるのである。計算䊅果は Table 2 の通 りである。

b) イソプロピルエーテルーイソプロパフール 実測值は Miller \& Blins 22) による 760 mmHg と括け るすのである。計算結果は Table 3 の通りである。な 特cの值は $c_{1}=5.5, c_{2}=4.9$ である。

c) 王タフール-水 実測值は Carey \& Lewis 5) による $760 \mathrm{mmHg}$ に挌けるるのである。計算結果は Table 4 の通りである。 $a_{1}=5.2, o_{2}=5.2$

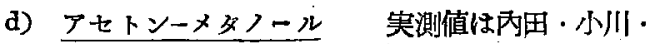

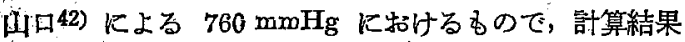
は Table 万の通りである。 $c_{1}=4.4, c_{2}=5.4$

以上の計算結果を実測值と比較したのが，Fig. 3 そ れを $x y$ 曲線仁移したのが Fig. 4 である。計算檤と実

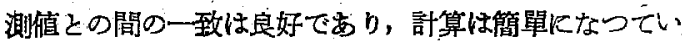
る。な特エタフールー水系では，共沸点汀度，曲り角

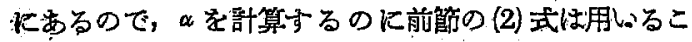
ではできなか力。

\section{§4. 平衡関保におよぼす圧の影翼}

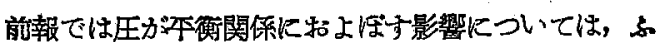
れなかつた。大粷左でない压に抢ける氣液本衡関係の信
Table 4

$\begin{array}{cccccc}x & T & k & k(1-x) & n & k \\ 0.9471 & 351.2 & -0.0535 & \begin{array}{c}-0.0503 \\ -0.052\end{array} & 1 & 0.95 \\ 0.0095 & 370.8 & 8.54 & \begin{array}{l}8.459 \\ 0.081\end{array} & 0.935 & 8.1 \\ 0.3619 & 354.1 & 0.431 & 0.156 & \frac{a_{1}}{00}=0.117 \rightarrow 0.42 \rightarrow 1.9\end{array}$

Table 5

\begin{tabular}{|c|c|c|c|c|c|}
\hline$x$ & $T$ & $\hbar$ & $h \underset{k x}{k(1-x)}$ & $n$ & $\alpha$ \\
\hline $\begin{array}{ll}\prime & 0.97\end{array}$ & 329.0 & -0.168 & $\begin{array}{l}-0.005 \\
-0.163\end{array}$ & 1 & 0.855 \\
\hline 0.025 & 336.8 & 1.30 & $\begin{array}{l}1.2675 \\
0.0325\end{array}$ & 0.935 & 1.92 \\
\hline$x_{m}=4.0$ & $25 *$ & 0 & \multicolumn{3}{|c|}{$* \frac{a_{1}}{a_{0}}=0.447 \rightarrow 0.72 \rightarrow 1.47$} \\
\hline
\end{tabular}
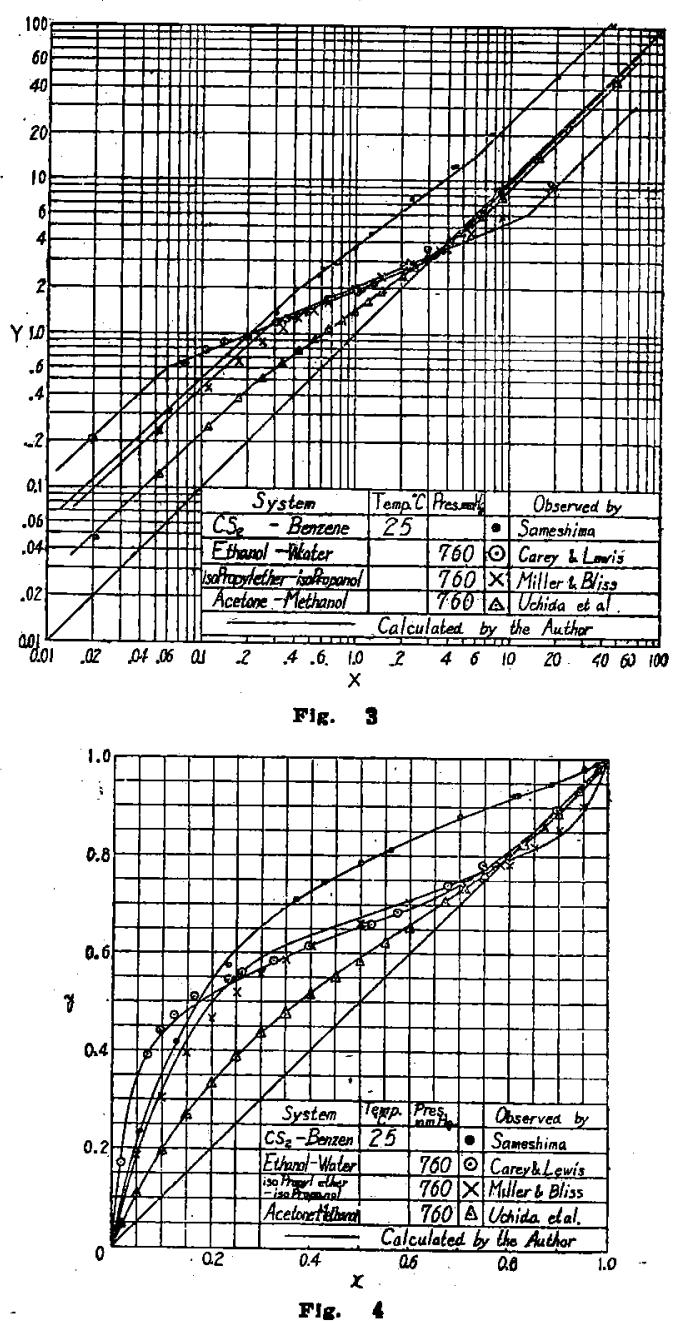


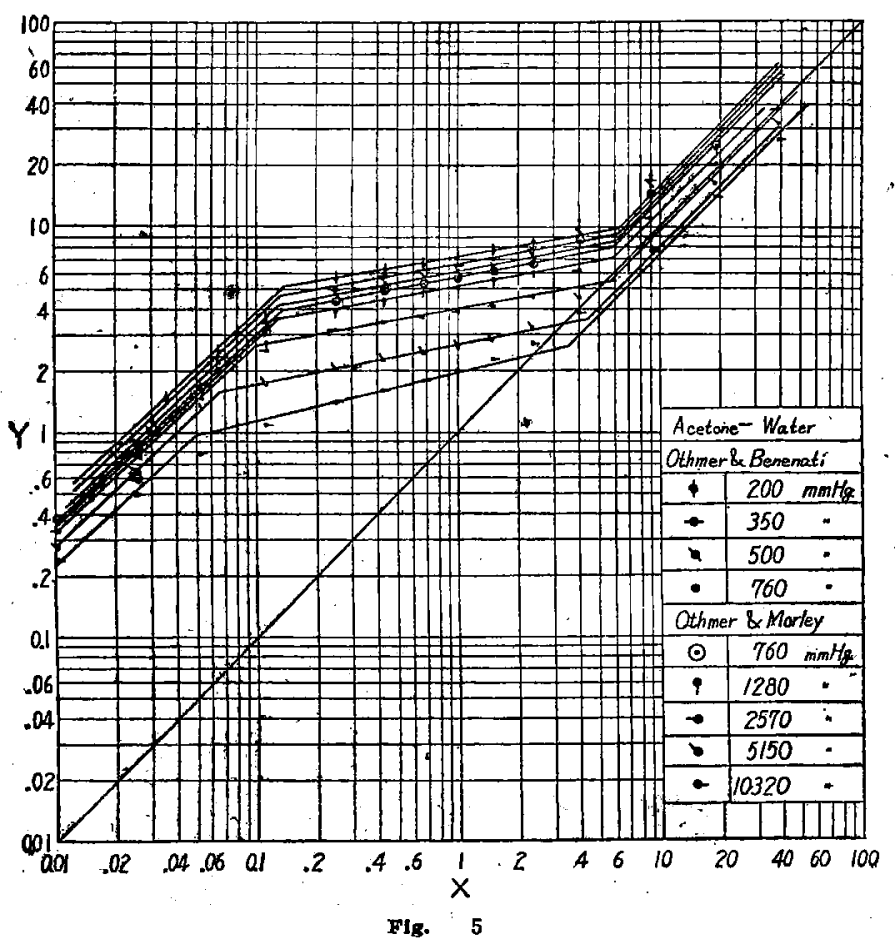

が高まるに從つて図上で下にさがつて くるむのである。 Fig. 5 は Othmer \& Benenati 26) の大氣圧以下の実測值 と Othmer \& Morley27) の大氣圧以上 のひのと色併記したるのであつて，禾 はアセトン-水である。最低 200 mmHg より $10320 \mathrm{mmHg}$ (或いは $200 \mathrm{lb} . / \mathrm{sq}$. in.) まで実測值である。なお，参考の. ために，溫度の变化淀溫の平矢関保 に括よばす影響杀みるために空素一酸 素の $74.7^{\circ} \mathrm{K}$ から $125.0^{\circ} \mathrm{K}$ までの卷 測值定 Fig. 6 に示した。こっです， 互に平行な関係が成立つていることが かかる。実測は， $74.7^{\circ} \mathrm{K}$ と $79.07^{\circ} \mathrm{K}$ 品 Inglis 19), $99.94^{\circ} \mathrm{K}, 110.05^{\circ} \mathrm{K}$, $119.92^{\circ} \mathrm{K}$ および $125.0^{\circ} \mathrm{K}$ が Krit. schewsky \& Torotscheschnikow 21) $\Sigma$ よるるのである。

次に，压の变化が前報でのべた計算 方法にどのような变化考與えるかにつ いてのベよう。まず計算の基碟になる 式は前報の(8)式でする。即ち

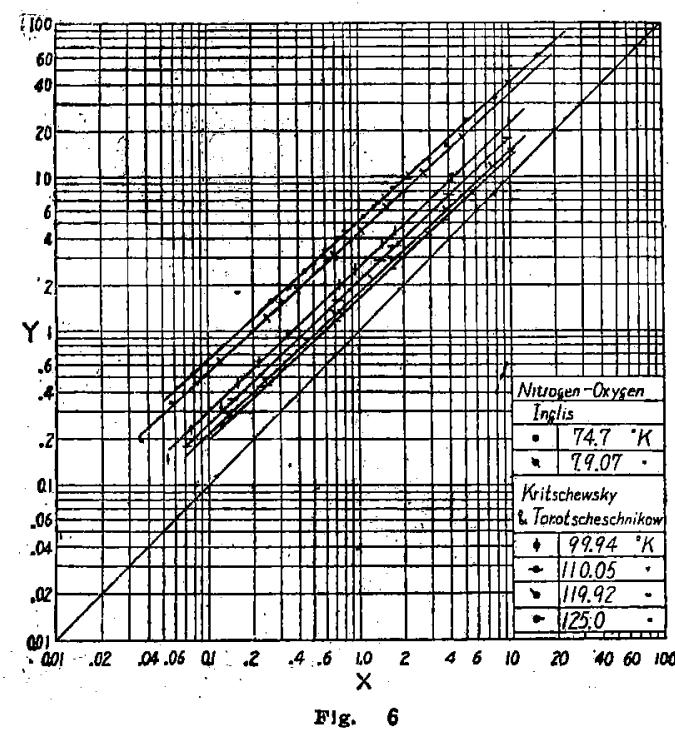

賴じうる央測値は少いので，本報でも断定的なことはい えないのであるが、大体次の上らな結果务得られた。

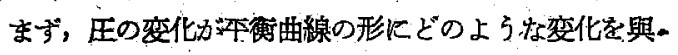
えるかについては，Fig.5、に見られる如く $X Y$ 曲粨の 位圈は，づれです形は装らないとさがわかつた。即ち相

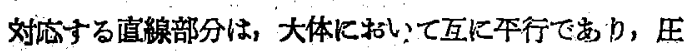

$$
\begin{aligned}
\left(\frac{x}{y}-\frac{1-x}{1-y}\right) \frac{d y}{d x} & =(C \log T \\
& -2.3 \log \pi) \frac{1}{T} \frac{d T}{d x}
\end{aligned}
$$

從つてkは次式で定義しなければならない。

$$
(C \log T-2.3 \log \pi) \frac{1}{T} \frac{d T}{d x}=-h
$$

これから先は，前報と全く同樣である。簡單に例をあけ て說明しょう。

a) 窒素一酸素 実測值は Dodge \& Dunbar 11) の $3800 \mathrm{mmHg}=5 \mathrm{~atm}$ Kおけるるのであつて, Raoult の 法則に從つて; その は2.64である。計算結果は Table 6 の通りであり，※は8.63 とでてきて; 殆んど 完全に一致する。この際，aとしては常圧に括ける値 4.9 をそのま〉用いている。

b) アセトンー水 実測値は Othmer \& Morley 27) .の, $5150 \mathrm{~mm} H \mathrm{~g}=6.775 \mathrm{~atm}$ Кおけるるのであつて, $X Y$ 曲線の上端の直線の $\alpha_{1}$ は 0.80 である。

計算結果は Table 7 の通りであつて， $\alpha_{1}$ は 0.78 と でてきて，対数方眼紙上では非常によい一致であるとい える。この場合にも $a_{1}$ として常压に括けるのと同じ值 4.4希用いている。

このよラにして，さし学つては，高圧に拀いても常圧 に粘けるcの值と同じ值を使用して，(4)式からにを訪 


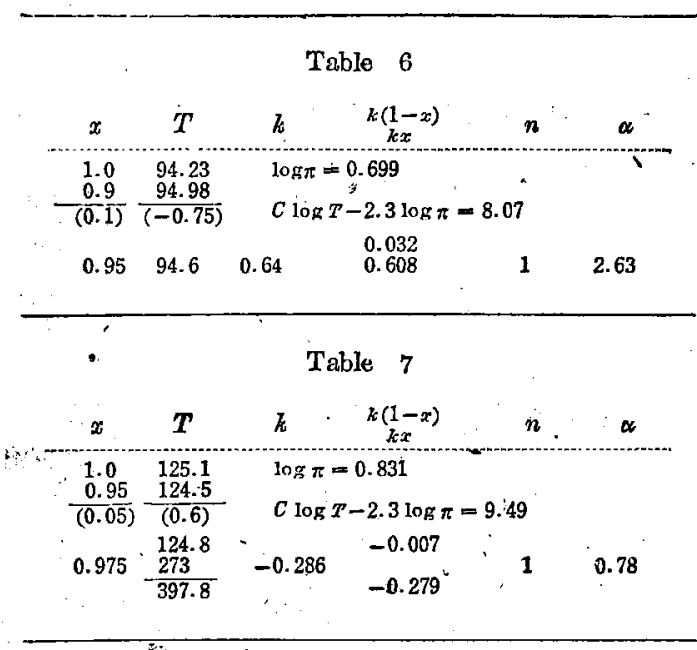

算すればよいということができる。

最後に本報でのべた $n$ と $\alpha_{1} / \alpha_{0}$ の相関関係は餘程圧 が高くならない限り，常压の場合と同樣に使用できるる ので努ることをつけ加えて报く。非常に高い性に対して はデータの不足からどの位誤差を生ず五か明らかでない

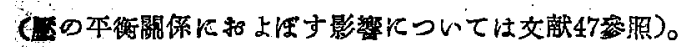

\section{使用記号}

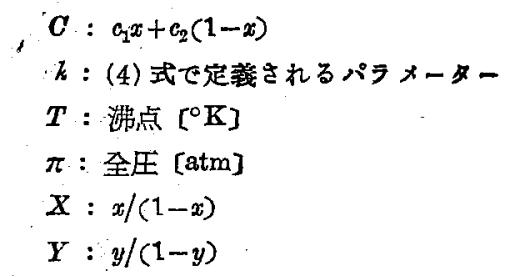

\section{空献}

1) Alpert \& Eiving, T. R.C. 41, 2864 (1949)

2) Bredig \& Bayer, $Z$. Phys. Chem., A 13), 1 (1927)

3) Bromiley \& Quiggle, r. R.C., 25, 1136 (1933)

4) Brinfes \& Furnas, Ibid., 27, 396 (1935)

5) Carey \& Lewls, Tbid., 24, 882 (1932)

6) Cariey \& Bertelsen, Ibid., 41, 2806 (1949)

7. Conner, Elving, Benischeck, Tobias \& Steingiser, rbia, 42, 106 (1950)

8) Conner, Elving \& Bteingiser, Ibtä., 40, 497 (1948)
9) Cornell \& Montonna, Ibid:, 25, 1331 (1933)

10) Dobson, J. Chem. Soc., 127, 2866 (1925)

11) Dođge de Dunbar, J. Am. Chem. Sac., 44, 608 (1927)

12) Duffy, reported by Perry, "Chem, Eng. Handbook,", 2nd. Ed. (1941)

13) Ferguson \& Funnell; J. Phys. Chems., 33, 1 (1929)

14) Furnas \& Lreighton, I. E. C. 23. 709 (1937)

15) Gadwá, reported by Perry, "Chem. Eng: Handboor," 2nd. Ed. (1941)

16) Gelus, Marple and Miller, I- E. C. 41, 1757 (1949)

17) Gilmont \& Othmer, Ibid., 33, 1061 (1944)

18) Griswold, Chy \& Winsauer, Ibidl. 41, 2352 (1949)

19) Inglis, Proc. Phys. Soc., 20, 152 (1906)

20) Jones, Schoenborn \& Colburn, $x . K . \dot{C}$., 35666 (1943)

21) Kritschewsky \& Torotscheschnlkow, $z$. phys. Chem., A 176, 338 (1936)

22) Miller \& Bliss, $T$. F. C., 32, 123 (1940)

23) Morton, $r$. Phys Chem:, 39,3841 (1929)

24) Olsen \& Washbum, J. Phys. Chem., 41, 457 (1937)

25) Othmer, $I . x . C ., 35,614$ (1943)

26) Othmer \& Benezati, Tbic,, 37, $299 \cdot(1945)$

27) Othmer \& Morley, Ibia., 38, 751 (1946)

28) Othmer \& Savitt, Ibid., 40, 168 (1948)

29) Perry, "Chemical Engineer's Handbook," 2nd. Ed. (1941)

30) Rieder \& Thompson, I. R. C. 41, 2905 (1949)

31) Rosanoff, Bacon \& Schulze, J. Am. Chem. Soc., 36, 1993 (1914)

32) Rosanopf \& Easeley, Ibid., 31, 979 (1909)

33) 壦禹, Jbid., 40, 1482, 1503 (1918)

34) Scatchard \& Raynond, Ibid, 60, 1275 (1938)

35) Scatchard, Wood \& Mochel, J. Phys. Chem., 43, 119 (1939)

36) - Schutz, J. Am. Chem. Șoc., 61, 2691 (1939)

37) Smith \& Mathesod, J. Research Natz. Bur. Standards., 20 , 641 (1938)

38) Stelnbauser \& whtie, . E. C., 41, 2912 (1949)

39) Tongberg \& Johnston, Ibid., 25, 733 (1933)

40) Tyrer, J. Chem. Sac., 101, 1104 (1912)

41） 內田・加藤，J. Soc. Chem. Ind. Japan, 37, 525 (1934)

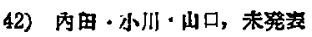

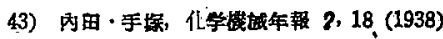

44) Wrewsky, Z. Phys. Chem., 81, 1 (1912)

45) Young, "Distillation Principles and Pracesses," (1922), p. 124.

46) Zawidzki, Ż. phys. Chem., 35, 129 (1900)

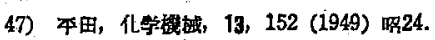

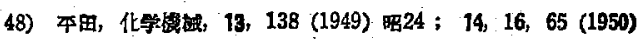
崚25.

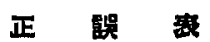

i. 14 卷 1 號 18 頁の (9) 式の分子の $x$ を $x_{1}$ とする。

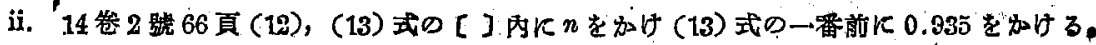

iii. 同 67 頁左側の下から $5,8,9$ 行で粗合せの數を示す（）の中の横線をとる。

iv, 同頁右㑡の Table 2 の中, n. Propyl aleohol のc の值 4.7 は 5.0 とする。 


\section{On the Vapor-Liquid Equilibrium-IV.}

A correlation and pressure effects

\section{Hirata.}

In two foregoing parte, methods are indicated for determining the equilibrium relation indirectly; where a trial and error method is necessary to ealculate the slope of the middle atraight portion of $X Y$ curve. Relatively simple as it may be, the trial and error method is unadvisable. In this paper, a correlation is found between $\alpha_{1} / \alpha_{0}$ and $n$, where

$\alpha_{1}$ : ordinate of the upper $X Y^{\prime}$ straight line

$a_{0}:$ ordinate of the lower $X Y$ straight line

and $n:$ slope of the middle $X Y$ straight line, respectively,

and its application is informed by several examples. Ef fects of pressure on the equilibrium relation and the method- of calculation are also discussed briefly.

\begin{tabular}{|c|c|c|}
\hline - * & $*$ & $*$ \\
\hline 「どらも近頃の會誌はむらかしい & & 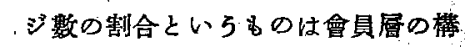 \\
\hline ばがクで面白くない」といら感じを & & 成舦合と對比して自然恋ってくる \\
\hline 抱きはじめたのはいつ頃からぢつた & & と思われる。そこで殘された問題は \\
\hline ろらか。その点はつきりしないが， & & 報文以外のベージをどのような內容 \\
\hline 益るての感老梁ぐしてをたこと性事 & & のるのにするかといらてとになる。 \\
\hline 苗である。このととは私一人ではな & & 現在でむ種々盛られている加，てれ \\
\hline いよらК思われるので, その由つて & & ら注なるでくやさしく親 \\
\hline ててれを卒直浑 & 会誌の改善を望む & にしでいい。そしてる \\
\hline Lネい:853ん & & のを名加えてみてはど \\
\hline 編集委員會の力 & めであろろ。紙數が制限されている & 央。 \\
\hline ，既炕抴諭調查 & 今日, 詳細は別 & 1）連載䛾座（初粐，中 \\
\hline あるから，蛇足 & 揭載するととと & 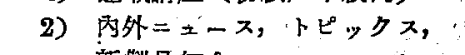 \\
\hline るが，現に會誌 & その概要または要 & 新熋品紹介 \\
\hline ら繰返し申达心 & 冒のみを紹介するてとにしてはどう & 总 (編 \\
\hline 厄はないである & 开究の陻被，目的並び & 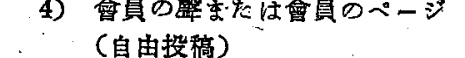 \\
\hline 5. & とその成果の應用範園といったとと & 學校, 研 \\
\hline いといらฺのは主と & が實は多くの誰者にとつて最も心ひ & 6) 學界, 業 \\
\hline 感じである。と & 办れる點であるととを念頭に入れ， & 7) 苦心录，失敗談，回 \\
\hline 時からみれぱ & その諭文が㯰者にとつて利用出來る & 初粐から高級まですべて \\
\hline 發達を逐げ; & 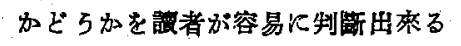 & 貝に同じととがこ \\
\hline 月的と出り分科 & よ5に，書いて頂けると幸である。 & レらことは到底不可能でる \\
\hline 呈自分の仕事K & 如何に立泿な研究です， それが利用 & それぞれの畨に沫 \\
\hline は，ちょつと哯 & されなければつをらないしまを立 & れぞれ揭载する \\
\hline いた位ではさっね゙り判るないためで & 派なるの程高度に利用されることが & に揭げを項目にはこのような考から \\
\hline 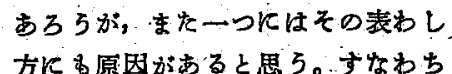 & 望ましいからである。 & $\begin{array}{l}\text { 出ためのを相當入れて招いた。「讀 } \\
\text { 者といらすのはどてか一部でる自分 }\end{array}$ \\
\hline 半端で, 砸究過程 & ベルを制定する最す有力な资料では & Кほんとらイマッチするところがあ \\
\hline ここたと逝へたす & あるが、そらかといつてそのすいて & れば大体滿是するものである。」 \\
\hline D俢 & てはない。䇥つて報文の占めるべー & (末i \\
\hline
\end{tabular}

